\title{
INVESTIGASI NIAT BELANJA ULANG KE TOKO PAKAIAN: PERAN CRM, KEPUASAN DAN LOYALITAS PELANGGAN
}

\author{
Aidha Savitri ${ }^{1)}$, Usep Suhud ${ }^{2}$ \\ ${ }^{1}$ Ilmu Komunikasi, London School of Public Relations \\ Email: savitri.aidha@gmail.com \\ ${ }^{2}$ Ilmu Komunikasi, London School of Public Relations \\ Email: usepsuhud@yahoo.com
}

\begin{abstract}
In this era of globalization the fashion industry in Indonesia is growing rapidly because public awareness for personal appearance is increasing. From many fashion brands, companies must have a strategy to stay afloat in business. Companies from various fashion industries must stay in touch with customers, through CRM or Customer Relationship Management in order to increase customer satisfaction that will make loyal customers that can affect repurchase intention. This study was conducted to find information from Customer Relationship Management to customer satisfaction and customer loyalty and how it impacts repurchase intention in a clothing store. This research was conducted by spreading questionnaires to 200 respondents using nonprobability sampling, convenience sampling. This research uses Exploratory Factor Analysis to test its validity and cronbach alpha to test the reliability. This research also uses a Structural Equation Model to test the hypothesis by using AMOS. From 5 hypotheses, in this research, 4 hypotheses have a positive and significant influence.
\end{abstract}

Keywords: customer relationship management, customer satisfaction, customer loyalty, repurchase intention.

\section{PENDAHULUAN}

Industri fashion di Indonesia sangat berkembang pesat karena di era globalisasi ini kesadaran masyarakat akan tampilan berbusana meningkat. Saat ini fashion tidak hanya dianggap untuk menutupi anggota tubuh tetapi untuk menunjukkan jati diri hingga status sosial.

Di era globalisasi dengan kemudahan informasi dan teknologinya membuat fashion di Indonesia juga dipengaruhi oleh budaya dari negara-negara lain seperti Amerika, Korea, Jepang, dll. Karena fashion dari negara-negara tersebut berkembang sangat pesat, peminat fashion nya pun bertambah dengan cepat.

Banyak perusahaan asing yang berlomba-lomba untuk membuka cabangnya di Indonesia. Bahkan jumlah toko ritel di Indonesia menempati urutan terbesar kedua di dunia setelah India (Kompas, 2011). Nielsen Executive Director Retail Measurement Services, Teguh Yunanto (dalam Kompas, 2011) mengatakan bahwa toko retail di Indonesia baik tradisional maupun modern terdapat sebanyak 2,5 juta toko dan $57 \%$ nya berada di Pulau Jawa. Salah satu yang menyumbang semakin bertambahnya jumlah toko ritel di Indonesia adalah toko pakaian khususnya di area Jakarta karena sebagai kota metropolitan akan membuat masyarakatnya lebih sadar dalam hal berpakaian.

Tetapi pada akhir tahun 2017 sudah ada beberapa perusahaan toko pakaian yang menutup beberapa gerainya bahkan ada yang menutup seluruh gerainya di Indonesia. Debenhams menutup seluruh gerai nya yang berada di Indonesia pada akhir tahun 2017 dan mengadakan diskon besar-besaran hingga diskon $70 \%$ (Tribun News, 2017), selain itu GAP juga sudah menutup toko nya yang terletak di Pondok Indah Mall II dan menyisakan toko nya di beberapa mal seperti Grand Indonesia, Lippo Mall Puri dan Surabaya Tunjungan Plaza 4. Tetapi GAP sudah berencana untuk menutup seluruh gerai nya namun belum diketahui kapan hal tersebut diputuskan (Tribun News, 2017).

Pada awal tahun 2018 ini, terdapat beberapa deretan toko asing yang menutup gerai nya di Indonesia seperti Banana Republic, New Looks, Dorothy Perkins dan Clarks, hingga mengadakan diskon besarbesaran hingga 50\%. (CNN Indonesia, 2018)

Tutupnya toko-toko ritel khusunya toko pakaian di Indonesia juga dikarenakan karena gaya hidup masyarakat sudah mulai 
berubah dan dengan adanya teknologi akan semakin mempersulit toko ritel untuk bersaing. Untuk mengatasi hal tersebut masing-masing toko clothing harus menggunakan berbagai strategi untuk tetap mempertahankan pelanggannya seperti, menginfokan produk dan layanannya kepada pelanggan secara rutin, menggunakan berbagai alat pemasaran untuk berkomunikasi dengan pelanggan, baik melalui media elektronik ataupun media tradisional. Selain itu juga harus melatih karyawannya untuk dapat membantu pelanggan dan memberikan rasa nyaman dan aman kepada pelanggan melalui gesture, sifat dan pengetahuannya mengenai produk atau layanan yang ditawarkan toko tersebut.

Tujuan dari berbagai strategi yang digunakan toko pakaian tersebut adalah untuk mengantisipasi dan mengenali kebutuhan pelanggan agar tetap menjadi pelanggannya dan hal-hal tersebut terangkum dalam satu kegiatan yang disebut CRM (Customer Relationshop Management). Dengan adanya CRM diharapkan dapat membantu suatu perusahaan untuk dapat mempertahankan pelanggannya. Sehingga dapat membuat pelanggannya terpuaskan, karena jika pelanggan sudah puas dengan layanan suatu perusahaan akan burujung baik bagi perusahaan itu sendiri. Berbagai komentar positif pun akan disebarkan dari pelanggan kepada orang-orang disekitarnya dengan begitu perusahaan tersebut pun akan semakin diuntungkan.

Selain itu perusahaan dapat membuat pelanggan loyal setelah kepuasan yang mereka rasakan. Pelanggan loyal juga harus dipertahankan karena dapat memberikan kontribusi dan pendapatan yang besar kepada perusahaan dan tidak hanya dari pelanggan baru produk tersebut. Jika perusahaan dapat mempertahankan pelanggan loyal, pembelian ulang pun akan terjadi dan perusahaan dapat menjauh dari kerugian atau bahkan yang lebih serius lagi yaitu menjauh dari kebangkrutan hingga penutupan gerainya. Berdasarkan pembahasan diatas, penelitian ini ingin membahas investigasi niat beli ulang pada toko pakaian melalui peran CRM, kepuasan dan loyalitas pelanggan.

\section{KAJIAN LITERATUR}

Teori Stimulus-Organism-Response (S-O-R)
Teori S-O-R dikembangkan oleh Mehrabian dan Rusell pada tahun 1974 (Pousttchi \& Wiedemann, 2010. p.354). Mar'at (dalam Ardianto, 2014, p. 134) mengatakan bahwa Teori S-O-R menitikberatkan pada proses pengertian yang banyak menyangkut komponen kognisi. Dalam teori Stimulus Response (S-R), masalah kognisi lebih diutamakan, sedangkan komponen afeksi diabaikan, sementara komponen konasi tergantung pada imbalan (ganjaran) dan hukuman sebagai akibat dari penguatan rangsangan. Di dalam pendekatan teori S-O-R, diutamakan cara-cara pemberian imbalan yang efektif agar komponen konasi dapat diarahkan pada sasaran yang dikehendaki. Sedangkan pemberian informasi adalah sesuatu yang penting untuk dapat menguban komponen kognisi.

Teori ini menggambarkan perubahan sikap, bergantung pada proses yang terjadi pada individu (Ardianto, 2014, p. 134)

a. Stimulus yang diberikan pada organisme dapat diterima atau ditolak. Jika stimulus ditolak oleh organisme, pada proses selanjutnya terhenti. Ini bahwa stimulus tersebut tidak efektif dalam memengaruhi organisme sehingga tidak ada perhatian (attention) dari organisme. Jika stimulus diterima oleh organisme, berarti adanya komunikasi dan perhatian dari organisme. Dalam hal ini, stimulus efektif dan ada reaksi.

b. Jika stimulus telah mendapat perhatian dari organisme, proses selanjutnya adalah mengerti terhadap stimulus (correctly comprehended). Kemampuan dari organisme inilah yang dapat melanjutkan proses berikutnya.

c. Pada langkah berikutnya adalah organisme dapat menerima secara baik apa yang telah diolah sehingga terjadi kesediaan untuk perubahan sikap.

Proses perubahan sikap ini terlihat bahwa sikap dapat berubah hanya jika rangsang yang diberikan benar-benar melebihi rangsang semula. Stimulus yang disampaikan pada organisme akan dijawab dengan adanya perhatian terhadap isi. Pada proses-proses ini terdapat kegiatan-kegiatan dari komponen kognisi yang memberikan informasi mengenai stimulus tersebut. Informasi ini diproses melalui proses belajar berdasarkan pengalaman. Informasi tersebut pada awalnya belum mempunyai arti, baru sampai pada taraf 
introspektif. Mar'at (dalam Ardianto, 2014, p. 135)

\section{Customer Relationship Management (CRM) \\ "CRM is the strategic process of} selecting the customers a firm can most profitably serve and of shaping the interactions between a company and these customers. The goal is to optimize the current and future value of the customers for the company" (Kumar \& Reinartz, 2006, p. 6).

Komponen dari definisi CRM diatas yaitu: (Kumar \& Reinartz, 2006, p. 6)

- Strategic process, artinya kegiatan CRM dibuat dan dikelola mulai dari posisi atau jabatan paling tinggi dari sebuah organisasi/perusahaan. CRM tidak hanya berlaku pada satu departemen tetapi memerlukan kontribusi dan bantuan dari semua sisi.

- Selection, jika semua pendapatan perusahaan berasal dari pelanggan, lebih baik perusahaan fokus kepada potential customer yang dapat meningkatkan keuntungan bagi perusahaan. Hal ini bukan untuk menolak pelanggan yang lainnya, tetapi untuk mengetahui dan mengenali segmentasi, perilaku dan karakteristik dari para pelanggannya.

- Interactions, hubungan antara perusahaan dan pelanggan harus menggunakan dialog interaktif.

- Customers, pelanggan disini tidak hanya end users tetapi meliputi distributor, retailer, dll.

- Current and future value of customer,

"Customer Relationship Management (CRM) is the process of carefeully managing detailed information about individual customers and all customer "touch points" to maximize loyalty. CRM is important because a major driver of company profitability is the aggregate value of the company's customer base." (Kotler \& Keller, 2016, p.168)

"CRM is not just about marketing, it is about how the whole company treats its customers" (Swift, 2001, p.63). Lalu inti dari Customer Relationship Management (CRM) adalah proses strategi suatu perusahaan untuk berinteraksi dengan pelanggannya agar dapat mengetahui kebutuhan pelanggan saat ini dan di masa yang akan datang sehingga dapat membawa keuntungan bagi perusahaan. Selain itu, CRM juga berguna untuk mengelola dan memantau perilaku pelanggan (Dyche, 2002, p.4).

\section{Customer Satisfation}

"In general, satisfaction is a person's feelings of pleasure or dissapointment that result from comparing a product or service's perceived performance (or outcome) to expectations." (Kotler \& Keller, 2016, p.153)

If you get what you want you are satisfied, if you don't you are not. (Szwarc, 2005, p.4). Berdasarkan kalimat yang dikemukakan tersebut, singkatnya kepuasan pelanggan yaitu jika yang pelanggan mendapatkan apa yang mereka inginkan tandanya mereka terpuaskan dan jika pelanggan tidak mendapatkan apa yang mereka inginkan maka mereka tidak terpuaskan.

McQuittty et al (dalam Widjaja, 2009, p. 51) mengungkapkan bahwa Customer Satisfaction merupakan dasar dari marketing concept. Naylor \& Kleiser (dalam Widjaja, 2009, p. 51) mengatakan customer satisfaction dapat menjadi salah satu alat yang baik untuk memprediksi future purchase behavior.

Oliver (dalam Widjaja, 2009, p. 52) mengatakan bahwa satisfaction dapat diperoleh konsumen dalam proses komunikasi yang disebut consumption experience. Setiap tahap konsumen dapat memberikan pernyataan persepsi terhadap kepuasan dan secara kolektif akan memberikan penilaian total (overall impresions). Lebih lanjut, konsumen dapat menjadi puas atau tidak puas pada tingkat yang berbeda-beda dan cenderung berharap menerima more satisfaction dari current satisfaction level dan mungkin menjadi tidak terpuaskan pada level yang lebih tinggi sehingga tingkat kepuasan sesungguhnya adalah abstrak.

\section{Customer Loyalty}

Formant (dalam Widjaja, 2009, p. 59) mengatakan bahwa definisi loyalitas pelanggan adalah hasil dari proses mempertahankan dan memaksimalkan hubungan dengan pelanggan serta memperluas hubungan melalui upaya-upaya menciptakan 
"nilai" serta menciptakan promosi dari mulut ke mulut (word of mouth).

Menurut Griffin (dalam Widjaja, 2009, p. 59) loyalitas pelanggan adalah sikap atau perilaku pembelian nonrandom untuk melakukan keputusan membeli secara terusmenerus terhadap produk atau jasa suatu perusahaan yang dipilih.

Sehingga Customer Loyalty dapat disimpulkan bahwa seorang pelanggan akan tetap memilih suatu produk berdasarkan komitmen yang dimiliki dan tinggi kemungkinan bahwa pelangan akan membeli kembali produk tersebut dan akan menyarankannya kepada orang disekitar.

Oliver (dalam Widjaja, 2009) mengatakan bahwa secara bertahap loyalty dapat terbentuk sebagai berikut :

1. Cognitive loyalty

Loyalitas pada level ini berdasarkan cognition semata, konsumen berdasarkan informasi yang diterima memperbandingkan produk/jasa yang satu dan lainnya dengan pemilihan keputusan pada informasi yang paling menarik bagi konsumen. Tingkat loyalitas pada tahap ini sangat labil dan konsumen sangat mudah berpindah.

2. Affective loyalty

Loyalitas yang berdasarkan pada affect dan sangat bergantung pada tingkat keupasan atau ketidakpuasan berdasarkan pada pengalaman konsumen menggunakan produk/jasa. Perlu menjadi catatan, tidak semua kepuasan konsumen menghasilkan loyalitas. Loyalitas pada tahap ini lebih tinggi tingakatannya dibandin cognitive karena pengalaman yang terekam dalam benak konsumen.

3. Conative loyalty

Konsumen menjadi berkomitmen karena percaya dan benar-benar berkeinginan membeli (intention) dan membeli kembali (repurchase) atau menjadi loyal.

4. Action loyalty

Pada tingkat ini intensitas pembelian konsumen menjadikan motivasi konsumen untuk secara terus-menerus membeli dan menjadi kebiasaaan membeli produk/jasa

Customer loyalty is the answer today as it has been in the past and will be in the future. Loyal customers are easier to do business with, are more predictable, and don't carry the expense associated with attracting new customers. Companies with a loyal customer base enjoy greater profitability in good economic times and depend on their loyal customers to help them survive difficult financial conditions. (Lawfer, 2004, p.12)

Berdasarkan kutipan diatas pelanggan yang loyal dapat membantu perusahaan untuk mendapatkan keuntungan yang lebih saat keadaan ekonomi sedang baik dan dapat membantu bertahannya suatu perusahaan saat keadaan ekonomi sedang memburuk.

\section{Repurchase Intention}

Repurcashe intention adalah evaluasi konsumen untuk melakukan pembelian kembali. Hellier, et al. (dalam Li dan Hong, 2013, p. 162). A satisfied consumer is more likely to purchase the product again and will also tend to say good things about the brand to others (Kotler \& Keller 2012, p.172).

Menurut Kotler \& Keller (2007, p.145) faktor-faktor yang mempengaruhi minat beli ulang yaitu:

Faktor Psikologis

Minat pelanggan untuk melakukan pembelian ulang didasari oleh pengalaman sebelumnya

Faktor Pribadi

Kepribadian pelanggan akan mempengaruhi keputusan pembelian

Faktor sosial

Keputusan untuk membeli dipengaruhi oleh orang-orang sekitar terutama keluarga.

\section{METODE PENELITIAN}

Penelitian ini akan menggunakan metodologi kuantitatif karena masalah yang ingin diteliti sudah jelas dan penelitian ini ingin mengetahui bagaimana perlakuan yang diberikan terhadap suatu perusahaan berpengaruh kepada pelanggannya. Pendekatan yang digunakan dalam penelitian ini adalah paradigma klasik (positivisme) yaitu untuk mengukur bagaimana sebab akibat dari suatu masalah yang ada. Cara berpikir dalam penelitian ini adalah secara deduktif yaitu, merupakan proses pengambilan kesimpulan sebagai akibat dari alasan-alasan yang diajukan berdasarkan hasil analisis data (Noor, 2011, p. 16).

Jenis Penelitian yang digunakan dalam studi ini adalah eksplanatif kausalitas yang merupakan penjelasan tentang apa penyebab 
dari peristiwa atau fenomena. Metode yang digunakan dalam penelitian ini adalah dengan cara survei yaitu menyebarkan kuisioner kepada 200 orang yang sudah pernah membeli pakaian dengan merek asing di toko ritel dan bertempat tinggal di Jabodetabek. Penelitian ini ingin mengetahui bagaimana pengaruh Customer Relationship Management terhadap customer satisfaction dan customer loyalty dan dampaknya pada repurchase intention.

Penelitian ini menggunakan teknik convenience sampling yang merupakan salah satu teknik yang ada dalam non-probability sampling.

\section{Uji Validitas \& Uji Reliabilitas}

"Validitas/kesahihan adalah suatu indeks yang menunjukkan alat ukur tersebut benar-benar mengukur apa yang diukur" (Noor, 2011, p. 130). Uji validitas yang digunakan dalam penelitian ini adalah Exploratory Factor Analysis dan Confirmatory Factor Analysis. Pada uji validitas ini akan disaring dan menghilangkan indikator yang dianggap tidak memenuhi standar.

"Reliabilitas/keterandalan ialah indeks yang menunjukkan sejauh mana suatu alat ukur dapat dipercaya atau diandalkan" (Noor, 2011, p. 130). Pada tahap uji reliabilitas yang menggunakan SPSS, terdapat indikatorindikator yang dihilangkan karena tidak memiliki nilai cronbach's alpha di atas 0,60 atau dinyatakan tidak valid.

Hasil Exploratory Factor Analysis Variabel Customer Relationship Management (CRM)

\begin{tabular}{|c|c|c|}
\hline \multirow{2}{*}{ Pernyataan } & \multicolumn{2}{|c|}{ Component } \\
\hline & 1 & 2 \\
\hline \multicolumn{3}{|c|}{ Dimensi 1} \\
\hline CRM1 & .909 & \\
\hline CRM2 & .875 & \\
\hline CRM12 & .846 & \\
\hline CRM14 & .699 & \\
\hline CRM5 & .656 & \\
\hline CRM8 & .544 & \\
\hline CRM13 & .513 & \\
\hline \multicolumn{2}{|c|}{ Cronbach's Alpha } & 0.878 \\
\hline \multicolumn{3}{|c|}{ Dimensi 2} \\
\hline CRM7 & & .888 \\
\hline CRM9 & & .733 \\
\hline CRM11 & & .721 \\
\hline CRM3 & & .698 \\
\hline CRM10 & & .697 \\
\hline CRM6 & & .476 \\
\hline
\end{tabular}

Cronbach's Alpha 0.839

Sumber: Data Olahan Peneliti, 2018

Berdasarkan hasil faktor analisis, variabel Consumer Relationship Management (CRM) terbagi menjadi 2 dimensi. Dimensi pertama memiliki 7 indikator dan dimensi kedua memiliki 6 indikator. Variabel CRM juga dinyatakan reliabel karena memiliki nilai cronbach's alpha diatas 0.60 .

Hasil Exploratory Factor Analysis Variabel Customer Satisfaction

\begin{tabular}{|c|c|c|}
\hline Pernyataan & $\begin{array}{c}\text { Componen } \\
\mathrm{t}\end{array}$ & $\begin{array}{c}\text { Cronbac } \\
\text { h's Alpha }\end{array}$ \\
\hline CS3 & .896 & \multirow{6}{*}{0.914} \\
\hline CS4 & .869 & \\
\hline CS1 & .865 & \\
\hline CS5 & .814 & \\
\hline CS6 & .806 & \\
\hline $\mathrm{CS} 2$ & .800 & \\
\hline
\end{tabular}

Sumber: Data Olahan Peneliti, 2018

Berdasarkan hasil faktor analisis, variabel customer satisfaction tidak memiliki dimensi tetapi terdapat 7 indikator. Variabel customer satisfaction dinyatakan reliabel karena memiliki cronbach's alpha diatas 0.60 .

Hasil Exploratory Factor Analysis Variabel Customer Loyalty

\begin{tabular}{|c|c|c|}
\hline \multirow{2}{*}{ Pernyataan } & \multicolumn{2}{|c|}{ Component } \\
\hline & 1 & 2 \\
\hline \multicolumn{3}{|c|}{ Dimensi 1} \\
\hline \multicolumn{3}{|c|}{.952} \\
\hline CL2 & \multicolumn{2}{|c|}{.934} \\
\hline Cron & lpha & 0.874 \\
\hline \multicolumn{3}{|c|}{ Dimensi 2} \\
\hline CL4 & & .924 \\
\hline CL3 & & .907 \\
\hline Cron & lpha & 0.805 \\
\hline
\end{tabular}

Sumber: Data Olahan Peneliti, 2018

Berdasarkan hasil faktor analisis, variabel customer loyalty terbagi menjadi 2 dimensi dengan masing-masing dimensi memiliki 2 indikator. Variabel customer loyalty dinyatakan reliabel karena memiliki cronbach's alpha diatas 0.60 .

Hasil Exploratory Factor Analysis Variabel Repurchase Intention

\begin{tabular}{|c|c|c|}
\hline Pernyataan & $\begin{array}{c}\text { Componen } \\
\mathrm{t}\end{array}$ & $\begin{array}{c}\text { Cronbach' } \\
\text { s Alpha }\end{array}$ \\
\hline RI1 & .949 & \multirow{3}{*}{0.940} \\
\hline RI3 & .930 & \\
\hline RI2 & .916 & \\
\hline
\end{tabular}


Berdasarkan hasil faktor analisis, variabel repurchase intention tidak memiliki dimensi tetapi terdapat 3 indikator. Variabel repurchase intention dinyatakan reliabel karena memiliki cronbach's alpha diatas 0.60 .

Setelah melalui Exploratory Factor Analysis terdapat 26 indikator yang tersisa dari 28 indikator pada tahap awal penelitian.

Hasil Confirmatory Factor Analysis

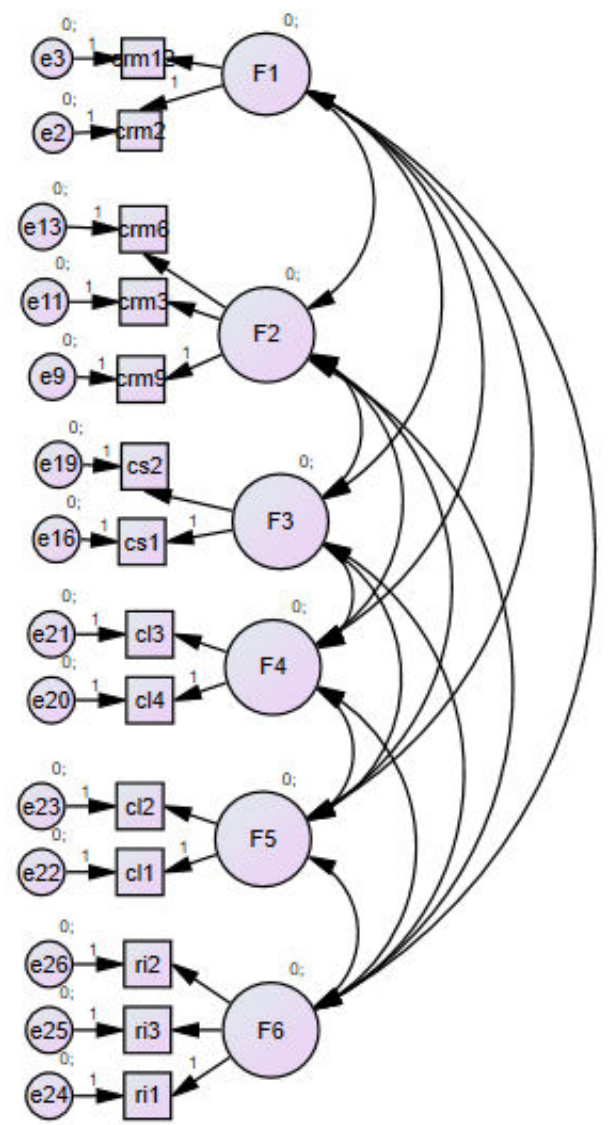

Sumber : Data Olahan Peneliti, 2018

Berdasarkan hasil Confirmatory

Factor Analysis jumlah indikator yang tersisa setelah dirontokkan sebanyak, 14 indikator dari 4 variabel yang diteliti.

Hasil Confirmatory Factor Analysis

\begin{tabular}{lrr}
\hline Kriteria & Hasil & \multicolumn{1}{c}{ Syarat } \\
\hline CMIN (P) & 0,122 & $\geq 0,05$ \\
RMSEA & 0.033 & $\leq 1,00$ \\
RFI & 0.941 & $\geq 0,90$ \\
NFI & 0.960 & $\geq 0,90$ \\
CFI & 0.993 & $\geq 0,90$ \\
IFI & 0.993 & $\geq 0,90$ \\
\hline
\end{tabular}

Sumber : Data Olahan Peneliti, 2018
Dapat disimpulkan bahwa model penelitian ini memenuhi syarat dan dapat dinyatakan sebagai model fit.

\section{Uji Hipotesis}

Uji hipotesis dapat menggunakan metode analisis dengan teknik analisis multivariat yang sering kali digunakan dalam penelitian kuantitatif, yaitu Structural Equation Model (SEM). Menurut (Noor, 2011, p. 226) analisis SEM menggabungkan dua buah model yaitu :

1. Model struktur (structural model), yang terdiri dari variabel laten eksogen (exogenous) dan variabel laten endogen (endogenous)

2. Model pengukuran (measurement model), yang merupakan indikator dari variabel laten eksogen dan endogen

Dengan kata lain permodelan SEM merupaka hybrid model.

Variabel dalam SEM (Noor, 2011, p. 227)

1. Variabel Laten

Variabel laten (unobserved variable) merupakan konsep abstrak, misalkan: kinerja, kecerdasandan motivasi.

Variabel laten dibedakan menjadi dua yaitu, variabel eksogen (exogenous) yang serupa dengan variabel bebas pada analisis jalur dan variabel endogen (endogenous) yang serupa dengan variabel terikat pada analisis jalur.

2. Variabel Teramati atau Variabel Terukur atau Variabel Manifes

Variabel teramati adalah variabel yang dapat diukur secara empiris, biasa disebut indikator.

Pada pengujian ini terdapat indikator yang dirontokan dan hasil Structural Equation Model adalah sebagai berikut. 


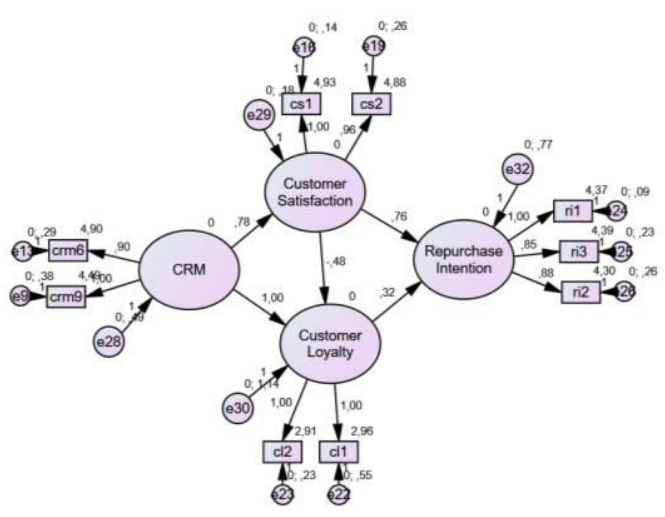

Sumber : Data Olahan Peneliti, 2018

Hasil Structural Equation Model

\begin{tabular}{lrr}
\hline Kriteria & \multicolumn{1}{l}{ Hasil } & \multicolumn{1}{l}{ Syarat } \\
\hline CMIN (P) & 0,381 & $\geq 0,05$ \\
RMSEA & 0.018 & $\leq 1,00$ \\
RFI & 0.967 & $\geq 0,90$ \\
NFI & 0.980 & $\geq 0,90$ \\
CFI & 0.999 & $\geq 0,90$ \\
IFI & 0.999 & $\geq 0,90$
\end{tabular}

Sumber : Data Olahan Peneliti, 2018

Dapat disimpulkan bahwa model penelitian ini memenuhi syarat dan dinyatakan sebagai model fit.

\section{HASIL DAN PEMBAHASAN}

Syarat hipotesis suatu penelitian diterima jika memiliki nilai critical ratio $\geq$ 1.980. Untuk hipotesis ditolak apabila nilai critical ratio $\leq 1.980$. Berdasarkan tabel hasil pengujian hipotesis, $\mathrm{H} 1, \mathrm{H} 2, \mathrm{H} 4$ dan $\mathrm{H} 5$ diterima karena nilai critical ratio $\geq 1.980$. Sedangkan H3 ditolak karena memiliki nilai critical ratio $\leq 1.980$.

Hasil Pengujian Hipotesis

\begin{tabular}{cccc}
\hline Hipotesis & $\begin{array}{c}\text { Hubu } \\
\text { ngan }\end{array}$ & C.R. & Hasil \\
\hline H1 & $\begin{array}{c}\text { CRM } \\
\rightarrow \text { CS }\end{array}$ & 8.020 & Diterima \\
& & \\
\hline H2 & CRM & 2.831 & Diterima \\
& $\rightarrow$ CL & & \\
\hline H3 & CS $\rightarrow$ & -1.479 & Ditolak \\
& CL \\
\hline H4 & CL $\rightarrow$ & 4.928 & Ditolak \\
& RI \\
\hline H5 & CS $\rightarrow$ \\
& RI \\
\hline
\end{tabular}

Sumber : Data Olahan Peneliti, 2018
Hasil pengujian hipotesis menjelaskan bahwa :

1. Hipotesis pengaruh Customer Relationship Management terhadap Customer Satisfaction pada toko pakaian ritel diterima karena nilai C.R. sebesar 8,020 . Syarat hipotesis diterima adalah C.R. $\geq 1.980$. Hasil ini didukung dengan penelitian sebelumnya dari (Ningsih, Suharyono, Yulianto, 2016) yang menyatakan bahwa Customer Relationship Management (CRM) memengaruhi Customer Satisfaction.

2. Hipotesis pengaruh Customer Relationship Management (CRM) terhadap Customer Loyalty toko pakaian ritel diterima karena nilai C.R. sebesar 2,831 dan nilai ini melebihi syarat diterimanya sebuah hipotesis yaitu $\geq$ 1.980. Hasil ini didukung dengan penelitian sebelumnya dari (Imasari, Nursalin, 2011).

3. Hipotesis pengaruh Customer Satisfaction terhadap Customer Loyalty pada toko pakaian ritel ditolak karena nilai C.R. sebesar $-1,479$. Nilai ini tidak memenuhi syarat sebuah hipotesis diterima yaitu $\geq$ 1.980. Oliver (dalam Widjaja, 2009) mengungkapkan bahwa pada tahapan affective loyalty tidak semua kepuasan konsumen menghasilkan loyalitas. Peneliti menyimpulkan bahwa Customer Satisfaction tidak sampai memengaruhi Customer Loyalty karena value dari sebuah produk pakaian terbilang rendah.

4. Hipotesis pengaruh Customer Loyalty terhadap Repurchase Intention pada toko pakaian ritel diterima karena nilai C.R. sebesar 4,928 dan nilai ini melebihi syarat diterimanya sebuah hipotesis yaitu $\geq$ 1.980. Hasil ini didukung dengan penelitian sebelumnya dari (Chinomona, Dubihlela, 2014) dan memiliki kemiripan yaitu membahas mengenai toko ritel.

5. Hipotesis Customer Satisfaction terhadap Repurchase Intention pada toko pakaian ritel diterima karena nilai C.R. sebesar 6,608 . Nilai tersebut memenuhi syarat sebuah hipotesis diterima yaitu $\geq 1.980$. Hasil ini didukung dengan penelitian sebelumnya dari (Curtis, Abratt, Dion, Rhoades, 2011) yang menyatakan bahwa Customer Satisfaction memengaruhi Repurchase Intention. 
Dikaitkan dengan teori Stimulus Organism - Response (SOR), yang menyatakan bahwa adanya perubahan sikap tergantung pada proses yang terjadi dalam individu melalui stimulus yang diberikan, penelitian ini membuktikan bahwa benar suatu stimulus dapat merubah suatu sikap melalui sebuah proses. Hasil penelitian ini menunjukkan bahwa stimulus yang diberikan yaitu Customer Relationship Management (CRM) dapat menimbulkan kepuasan dan loyalitas pelanggan sehingga terjadi perubahan sikap seorang pelanggan dan akan berniat untuk melakukan pembelian ulang.

\section{KESIMPULAN}

Berdasarkan hasil penelitian yang telah dilakukan, berikut adalah hasil dari model penelitian ini.

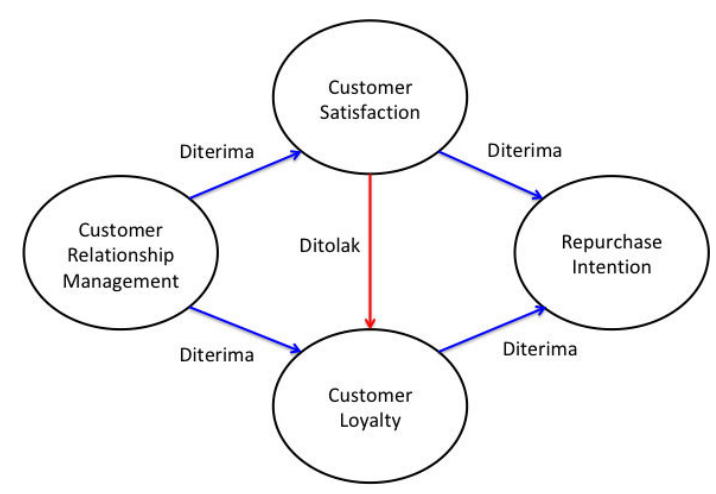

Sumber: Data Olahan Peneliti, 2018.

Berdasarkan tabel di atas penelitian ini memiliki hasil sebagai berikut:

1. Customer Relationship Management (CRM) toko pakaian ritel memiliki pengaruh positif dan signifikan terhadap Customer Satisfaction.

2. Customer Relationship Management (CRM) toko pakaian ritel memiliki pengaruh yang positif dan signifikan terhadap Customer Loyalty

3. Customer Satisfaction pada toko pakaian ritel tidak memiliki pengaruh terhadap Customer Loyalty

4. Customer Loyalty pada toko pakaian ritel memiliki pengaruh yang positif dan signifikan terhadap Repurchase Intention

5. Customer Satisfaction pada toko pakaian ritel memiliki pengaruh positif dan signifikan terhadap Repurchase Intention.

\section{REFERENSI}

Ardianto, E. (2014). Metodelogi Penelitian untuk Public Relations Kuantitatif dan Kualitatif. Bandung: Simbiosa Rekatama Media.

Chinomona, R., \& Dorah, D. (2014, May). Does Customer Satisfaction Lead to Customer Trust, Loyalty and Repurchase Intention of Local Store Brands? The Case of Gauteng Province of South Africa . Journal of Social Sciences , 5. Diperoleh dari https://www.google.com/url?sa=t\&rct $=\mathrm{j} \& \mathrm{q}=\&$ esrc $=\mathrm{s} \&$ source $=$ web $\& \mathrm{~cd}=1 \&$ $\mathrm{cad}=\mathrm{rja} \& u a c t=8 \& \mathrm{ved}=0$ ahUKEwimrt Sist_YAhXCU7wKHeKoAG0QFggr MAA\&url=http\%3A\%2F\%2Fwww.m cser.org\%2Fjournal\%2Findex.php\%2 Fmjss\%2Farticle\%2Fdownload\%2F26 08\%2F2576\&usg=AOvVaw2Afw1ttiu jPODSjlABgR9g

CNN Indonesia. (2018). CNN Indonesia. Diperoleh dari CNN Indonesia Website: https://www.cnnindonesia.com/ekono $\mathrm{mi} / 20180205175317-94-$

273957/deretan-ritel-impor-yangtutup-toko-di-awal-tahun/1

Curtis, T., Abratt, R., Dion, P., \& Rhoades, D. L. (2011). Customer Satisfaction, Loyalty and Repurchase: Some Evidence from Apparel Consumers. Management, Marketing \& Operations. Diperoleh dari https://commons.erau.edu/cgi/viewcon tent.cgi?referer=https://www.google.c $\mathrm{om} / \&$ httpsredir $=1 \&$ article $=1020 \& \mathrm{cont}$ ext=db-management

Dyche, Jill. (2002). The CRM Handbook: A Business Guide to Customer Relationship Management. USA: Addison - Wesley.

Imasari, K., \& Nursalin, K. K. (2011, Desember). Pengaruh Customer Relationship Management Terhadap Loyalitas Pelanggan pada Pt Bca Tbk. Fokus Ekonomi, 10(3). Diperoleh dari https://www.unisbank.ac.id/ojs/index. php/fe2/article/view/474 
Kompas (2011, Maret 15) Jumlah Toko di RI Terbesar Kedua Dunia. Diperoleh dari Kompas Web site: http://ekonomi.kompas.com/read/2011 /03/15/12333392/Jumlah.Toko.di.RI.T erbesar.Kedua.Dunia

Kotler, \& Keller. (2007). Manajemen Pemasaran Edisi 12, Jilid 1. Jakarta: PT. Indeks

Kotler, \& Keller. (2012). Marketing Management (14th edition ed.). New Jersey: Pearson Education, Inc .

Kotler, \& Keller. (2016). Marketing Management. Harlow: Pearson Education, Inc.

Kumar, V., \& Reinartz, W. J. (2006). Customer Relationship Management A Databased Approach. John Wiley \& Sons, Inc.

Lawfer, R Manzie. (2004). Why Customers Come Back. USA: Career Press.

Ningsih, N. W., Suharyono, \& Yulianto, E. (2016, January). Pengaruh Customer Relationship Management (CRM) Terhadap Kepuasan (Survei pada Pelanggan PT Astra Internasional, Tbk-TSO AUTO2000 Cabang Denpasar) dan Loyalitas Pelanggan. Jurnal Administrasi Bisnis , 30. Diperoleh dari http://administrasibisnis.studentjournal .ub.ac.id/index.php/jab/article/view/12 $01 / 1383$

Noor, J. (2011). Metodologi Penelitian, Prenada Media Group. Jakarta: Curriculum Standards for Social Studies.

Pousttchi, K., \& Wiedemann, D. G. (2010). Hand of Bokk Research On Mobile Marketing Management. New York: Business Science Reference.

Swift, R. S. (2001). Accelerating Customer Relationship. Amerika: Prentice Hall PTR.

Szwarc, P. (2005). Researching Customer Satisfaction \& Loyalty. London: Market Research In Practice.

Tribun Bisnis. (2017). Tribun News. Diperoleh dari Tribun News Website: http://www.tribunnews.com/bisnis/201 7/12/30/toko-toko-ritel-berguguransepanjang-tahun-2017?page $=3$

Widjaja, B. T. (2009). Lifestyle Marketing. SERVILIST: Paradigma Baru Pemasaran Bisnis Jasa Dan Lifestyle. Bandung: PT Gramedia Pustaka Utama. 